\title{
Using the Theory of Planned Behaviour (TPB) in Predicting the Intent to Use the Internet for Academic Purposes
}

\author{
ZAINOL BIDIN ${ }^{1}$ \\ MOHD FARID ASRAF MD HASHIM ${ }^{2}$ \\ ZAKIYAH SHARIF ${ }^{3}$ \\ FARIDAHWATI MOHD SHAMSUDIN ${ }^{4}$ \\ College of Business \\ Universiti Utara Malaysia \\ b.zainol@uum.edu.my ${ }^{l}$ \\ mdfarid@uum.edu.my ${ }^{2}$ \\ zaez2205@uum.edu.my \\ faridah@uum.edu.my ${ }^{4}$
}

\begin{abstract}
Purpose - This study sought to investigate the factors that influence students' intention to use the Internet for academic purposes in Universiti Utara Malaysia. This study applies theory of planned behaviour (TPB) as the base model. The model employed the original variables from the theory i.e. attitudes, subjective norms, perceived behavioural control and intention.
\end{abstract}

Method - A survey involving of questionnaires was conducted among 369 public university students. Multiple regression was employed to examine the factors influencing intention to use the Internet for academic purposes.

Findings - Results revealed that the variables attitude, subjective norms, and perceived behavioural control are statistically significant in influencing intention to use the Internet for learning purposes. It was also found that $38 \%$ of the variance in students' intention to use the Internet is cumulatively explained by their attitude, subjective norms, and perceived behavioural control.

Significance - The paper provides useful scientific insight into the relationships between attitude, subjective norms and perceived behavioural control variables towards intention to use the Internet 
for academic purposes. The findings can be used to promote the use of Internet among students in enhancing their learning experience.

Keywords: Attitude, subjective norm, perceived behavioral control, intention.

\section{INTRODUCTION}

In the past few decades, Internet technologies have played an important role in the personal and even professional lives of many people. At the personal level, individuals routinely use Internet technology especially for various purposes such as for communicating with others, doing online shopping, paying bills or managing bank accounts. At the professional level, the Internet is used for communicating with clients, and sharing knowledge across organizations, to name a few. In general, the Internet has opened up various opportunities that were not imaginably possible then. As a gateway of information, it has transformed substantially the way we interact with each other and the way we lead our lives.

The Internet offers limitless possibilities in higher learning institutions. Many universities have taken advantage of the new communication technology made possible by Internet technology by integrating it with the existing curriculum to make learning and teaching experiences more interactive and attractive. As a result, many universities have provided relevant infrastructure toward this end so as to make sure that students and teachers alike will not be left behind by the new Internet-driven technology. For example, on many campuses, students are able to use wireless hotspots to access course materials. The students in particular are now able to benefit from the new technology in preparing themselves to deal with the real challenges at the workplace after they graduate.

The Internet has indeed transformed the way learning and teaching is conducted. The traditional way of chalk and blackboard has given way to e-learning and e-teaching with the assistance of the Internet. Students have more access to learning materials made available on the web. While the Internet should, theoretically speaking, enhance students' learning experience through the vast amount of information made available to them on the web, many studies have documented that students spent much of their time using the Internet for non-academic activities and purposes. For example, a study conducted by Pew Internet and American Life (2000, as cited in Asfaw \& Bo, 2003) documented that many college 
students used the Internet for social activities like communicating with friends rather than for academic-related purposes. A similar finding is reported by Chan and Fang (2007), who investigated the use of the Internet among young people in Hong Kong. Aiken, Vanjani, Ray, and Martin (2003), in their study of college students in two US universities, found that the respondents indicated that they spent more time (in terms of hours) on the Internet for e-mail than for educational purposes. Yalcinalp and Moeini (2008) also found the same usage pattern by students, who reported that the Internet was mostly used for e-mail and chatting and less for educational purposes.

The current evidence that shows that college students spend more time on the Internet for non-academic purposes has led to our investigation of the factors that influence college students' intention to use the Internet for learning purposes in Malaysia. Such an issue is important to study given that college students are the potential leaders in the society and to be able to lead the society well and effectively, they need to be equipped with the relevant and necessary knowledge. The Internet offers such an advantage to the students that they not only become technologically savvy, which is an important asset that students should obtain, but they should also become part of a the knowledgeable society. We explored the issue among final year business undergraduate students enrolled in Universiti Utara Malaysia, using the theory of planned behaviour as the underlying perspective.

\section{LITERATURE REVIEW}

\section{Theory of Planned Behaviour}

The theory of planned behaviour (TPB) is used as the underlying perspective for the present study because it has received strong empirical support that attitude and subjective norm are important in affecting intention (Ajzen \& Fishbein, 1980; Fishbein \& Ajzen, 1975). TPB is an extended theory from TRA by incorporating an additional construct, namely perceived behaviour control (PBC). Ajzen (1988) adds perceived behaviour control to capture the factors beyond an individual's control towards the achievement of behavioural goals. In TPB, there are three independent determinants of intention towards behaviour, i.e. attitudes, subjective norm, and perceived behavioural control (Ajzen, 1991). Intentions are assumed to capture the motivational factors that influence behaviour. They 
are indications of how hard people are willing to try, of how much of an effort they are planning to exert, in order to perform the behaviour (Ajzen \& Driver, 1992). This intention-based model has been widely applied to diverse disciplines such as health, leisure choice, psychology and information technology (Ajzen, 1988; Ajzen \& Driver, 1992; Mathieson, 1991; Taylor \& Todd, 1995). In the information-system related field, researchers have also found empirical support for predicting the intention on the adoption of new technologies by using TPB (Harrison, Mykytyn, \& Riemenschneider, 1997; Taylor \& Todd, 1995; Yi, Jackson, Park \& Probst, 2006).

\section{Attitude}

Attitude towards performing a behaviour refers to perceptions of personal desirability to perform the behaviour (Ajzen, 1987). It depends on the expectations and beliefs about personal impacts of outcomes resulting from the behaviour. According to Ajzen and Fishbein (1980), a person's attitude towards a behaviour represents an evaluation of the behaviour and its outcome. TPB as well as TRA has found that attitude is a significant factor in defining webshopping behaviour. Limayem, Kalifa, and Frini (2000) found that attitude towards web-shopping behaviour would positively predict intention to use the web for product information search which would affect web-shopping intention. O'Cass and Fenech (2003) found - that attitude towards web for retailing can influence behaviour of using the web for retail purchases. Another study by Jong and Wang (2009) also found that attitude significantly influences web-based learning system. In this study, attitude is determined by a student's subjective evaluation of the consequences of using the technologies. Based on the foregoing discussion, the following hypothesis is proposed:

H1: Attitude towards Internet usage for academic purposes is positively related to the intention to the use the Internet for academic purposes.

\section{Subjective Norm}

In TPB, subjective norm is defined as "the perceived social pressure to perform or not to perform the behaviour' by the individual (Ajzen, 1991). Alternatively, subjective norm refers to the person's perception of the social pressures for or against performing the 
behaviour in question (Ajzen, 1987). TPB holds that subjective norm is a function of beliefs. Beliefs that underlie the subjective norm are called normative beliefs. Thus, if a person believes that the most important referents think that a behaviour should be performed, then such pressure will trigger the individual's intention to perform the behaviour in question. The referents here refer to a group of people who are close to the individual, for instance family, peers, spouse, close friends, teachers, and any people who are important in his/ her life. Many studies have found that the subjective norm is an important determinant of behavioural intention to use information technology (Fusilier \& Durlabhji, 2005; Hartwick \& Barki, 1994; Jong \& Wang, 2009; Moore \& Benbasat, 1993). Based on the above argument, the following hypothesis is put forward:

$\mathrm{H} 2$ : Subjective norm is positively related to intention to use the Internet for academic purposes.

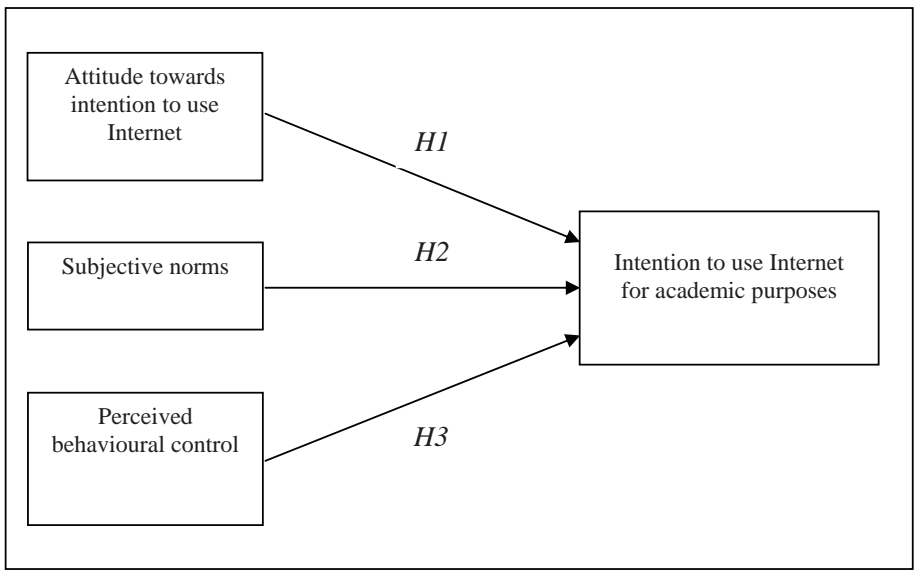

Figure 1. Research Framework

Figure 1 illustrates the framework used to achieve the research objectives of the present study based on the TPB model.

\section{Perceived Behavioural Control}

Perceived behavioural control reflects the perceived ability to execute a target behaviour (Ajzen, 1987). It relates to an individual's perception of the degree of ease and difficulty in performing such 
behaviour, and it is assumed to reflect past experience as well as anticipated obstacles (Ajzen \& Driver, 1992). This construct is affected by perceptions of access to necessary skills, resources and opportunities to perform the behaviour. If an individual does not have control over the circumstances, the individual may not have any or less intention to perform a particular behaviour. In behaviour intention research, perceived behavioural control has been found to be of a concern determinant of usage intention (Fusilier \& Durlabhji, 2005; Mathieson, 1991). A study on technology usage such as the effect of computer self-efficacy, user-involvement and mandatory use of IT (Compeau \& Higgins, 1995; Hartwick \& Barki, 1994; Moore \& Benbasat; 1993) also found the same result. Thus, based on the above discussion, the following hypothesis is proposed:

H3: Perceived behavioural control is positively related to intention to use the Internet for academic purposes.

\section{RESEARCH METHODOLOGY}

\section{Procedure}

We conducted a cross-sectional study in which questionnaires - were distributed to final-year undergraduate business students undertaking various business-related programmes such as marketing and accounting in Universiti Utara Malaysia (UUM). This group of students was randomly chosen because they have been exposed to the higher education environment and the learning process for a reasonable period of time, and hence had experience in Internet application for academic purposes. 420 self-administered questionnaires were distributed, but only 369 were returned which represented a response rate of $88 \%$.

\section{Measurement}

The questionnaires were borrowed from Fusilier and Durlabhji (2005). The instrument consisted of four different constructs. Measures of attitude, subjective norm, perceived behavioural control and intention were phrased as questions on a five-point Likert scale from $1=$ strongly disagree to $5=$ strongly agree. There were four items on attitude, two items on subjective norms, three items on perceived behavioural control and two items on intention. 
Among the items on attitude were "I like the idea of using the Internet for my course learning content", and "Using the Internet to learn the course content would be pleasant", while items such as "People who influenced my behaviour think that I should use the Internet to learn the course content" and "People who are important to me think that I should use the Internet to learn the course content" were asked to measure subjective norms. Perceived behavioural control was measured via items such as "Using the Internet to learn the course content is entirely within my control" and "I am able to use the Internet to learn the course content", and finally intention was measured via items such as "Assuming I have access to the Internet, I intend to use the Internet to learn the course content" and "Given that I have access to the Internet, I predict that I would use the Internet to learn the course content".

\section{FINDINGS}

\section{Respondents' Profile}

As shown in Table 1, respondents comprised approximately $48 \%$ Chinese, $42 \%$ Malays, and $10 \%$ Indians. The majority were female (84\%). Almost $70 \%$ of the participants had a cumulative grade point average (CGPA) of between 3.00 and 3.66, while only a few had achieved a CGPA of between 3.67 and 4.00.

\section{Table 1}

Respondents' Profile

\begin{tabular}{|c|c|c|}
\hline Items & Frequency & Percentage $(\%)$ \\
\hline $\begin{array}{l}\text { Gender } \\
\quad \text { Male } \\
\text { Female }\end{array}$ & $\begin{array}{r}59 \\
310\end{array}$ & $\begin{array}{l}16.0 \\
84.0\end{array}$ \\
\hline $\begin{array}{l}\text { Ethnicity } \\
\text { Malay } \\
\text { Chinese } \\
\text { Indian } \\
\text { Other }\end{array}$ & $\begin{array}{r}152 \\
177 \\
24 \\
16\end{array}$ & $\begin{array}{r}41.2 \\
48.0 \\
6.5 \\
4.3\end{array}$ \\
\hline $\begin{array}{c}\text { CGPA score } \\
3.67-4.00 \\
3.00-3.66 \\
2.00-2.99 \\
\end{array}$ & $\begin{array}{r}18 \\
243 \\
106 \\
\end{array}$ & $\begin{array}{r}4.8 \\
65.9 \\
28.7 \\
\end{array}$ \\
\hline
\end{tabular}




\section{Reliability Analysis}

The alpha values of the reliability analysis for all of the four constructs, as shown in Table 2, attained more than .70 which is acceptable (Hair, Anderson, Tatham, \& Black, 1998; Nunnally, 1978). The items for the construct of attitude, subjective norms, perceived behavioural control, and intention achieved reliability coefficients of .76, .86, 0.75 and .89 , respectively. In sum, it can be said that the constructs reliability levels are adequate.

\section{Table 2}

Reliability Analysis

\begin{tabular}{lcc}
\hline \multicolumn{1}{c}{ Variables } & No. of items & Cronbach's alpha \\
\hline Attitudes & 4 & .76 \\
Subjective norms & 2 & .86 \\
Perceived behavioural control & 3 & .75 \\
Intention & 2 & .89 \\
\hline
\end{tabular}

Table 3

Multiple Regression Analysis

\begin{tabular}{|cccccc} 
Unstandardized Coefficients & & & \multicolumn{3}{c}{$\begin{array}{c}\text { Standardized } \\
\text { Coefficients }\end{array}$} \\
\hline Constant & $\mathrm{B}$ & Std. error & Beta & $\mathrm{T}$ & Sig. \\
\hline Attitude & .517 & .457 & & 1.130 & .259 \\
Subjective norm & .202 & .029 & .337 & 7.061 & $.000^{*}$ \\
Perceived behavioural control & .278 & .041 & .334 & 6.864 & $.000^{*}$ \\
\hline
\end{tabular}

Note: $* \mathrm{p}<.01 ; * * \mathrm{p}<.05$.

\section{Multiple Regression Analysis}

Before multiple regression was run, the assumptions of the test were examined. It was found that none of the assumptions of outliers, i.e. 
outliers, normality, linearity, homocedasticity, multicollinearity, and independence of errors were met. Results from multiple regression showed that adjusted R square was 0.38 and the F-Ratio was 75.42. This reflects that $38 \%$ of the variables in the intention of Internet usage for academic purposes were significantly explained by the independent variables. Table 3 shows that attitude and perceived behavioural control significantly influence intention at $\mathrm{p}<.01$. Meanwhile, subjective norm significantly influences intention to use the Internet for academic purposes at $\mathrm{p}<.05$. Standardized coefficients were $.337, .093$ and .334 , respectively. Therefore, H1, $\mathrm{H} 2$ and $\mathrm{H} 3$ were supported.

\section{DISCUSSION}

The aim of this study was to investigate the intention of business students to use the Internet for academic purposes, using the Theory of Planned Behaviour (TPB) as the underlying framework. Three hypotheses were formulated and all of them received empirical support, suggesting that TPB is appropriate in explaining intention to use the Internet for academic purpose by business students. In this context, the present study's findings are consistent with those of previous research that used the same theory (Fusilier \& Durlabhji, 2005; Hartwick \& Barki, 1994; Jong \& Wang, 2009; Moore \& Benbasat, 1993).

The finding of the present study showed that attitude, subjective norms and perceived behavioural control variables are statistically significant determinants of Internet use, based on the TPB model. With respect to the predictive power of the determinants of students' intention to use the Internet for learning purposes, the present study revealed that attitude towards using the Internet is the strongest predictor followed by perceived behavioural control and subjective norms, as indicated by the Beta coefficients in Table 3. It can be said that business students were influenced by their referents in using the Internet, parallel to the finding of Fusilier and Durlabhji (2005). The result also indicates that ability and controllability would affect the intention of business students in using the Internet for academic purposes. This study further found that accounting students with positive attitudes of the Internet were keen to use it in their studies. This is consistent with the findings revealed by Noor Ismawati (2003) who found that in general, the majority of her 
respondents did use computers for assignments and communication using the Internet, as well as for searching academic and nonacademic resources.

In sum, TPB has provided useful insights into predicting the intention of Internet use for academic purposes among business students. Such a finding has important practical implications for enhancing students' learning processes with the use of the Internet. To do that, university administrators and educators should create an environment that cultivates positive attitude and perception of using the Internet for academic purposes so that such attitudes are translated into favourable learning behaviour and hence outcomes (Fusilier \& Durlabhji, 2005). This can be done by fostering webbased learning and online communication between academics and students. Developing and implementing the necessary learning infrastructure to enhance and facilitate ease of use and perceived usefulness of the Internet is a prerequisite to favourable learning experience at the higher education institutions. Furthermore, shortterm Internet courses or workshops can be offered to help students who are not familiar with the computer and the Internet technology in order to develop their sense of self efficacy and ease of use. By doing so, their attitudes toward the Internet will be positive.

$\square$

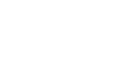

\section{LIMITATIONS AND FUTURE RESEARCH}

The findings of the present study should be interpreted with caution given some limitations. The first limitation is that this study only covered final year business students of Universiti Utara Malaysia. We have made an assumption that at this level, these students had been exposed to the higher education environment and had reasonable knowledge of information technology particularly Internet application. Hence, the findings may not be generalizable to all business students in Malaysia mainly because of the different learning environments and settings in the different higher learning institutions that might affect students' views and opinions on Internet use. For this reason it is recommended that in the future, a more comprehensive study should be conducted on both public and private universities and colleges in Malaysia to ensure better generalizability. Future research also should explore the influence of ethnicity, gender, computer skills and accessibility outside the 
campus because these factors may have a bearing on the extent of their exposure to Internet technology and hence their attitude and behaviour towards using it for learning purposes.

\section{REFERENCES}

Aiken, M., Vanjani, M., Ray, B., \& Martin, J. (2003). College students' internet use. Campus-Wide Information Systems, 20(5), 182-185.

Ajzen, I., \& Fishbein, M. (Eds.). (1980). Understanding attitudes and predicting social behaviour. New Jersey: Prentice-Hall.

Ajzen, I. (1988). Attitudes, personality and behaviour. Chicago, IL: Dorsey.

Ajzen, I. (1991). The theory of planned behaviour. Organizational Behaviour and Human Decision Process, 50(2), 179-211.

Ajzen, I., \& Driver, B. L. (1992). Application of the theory of planned behaviour in leisure choice. Journal of Leisure Research, 24(3), 207-224.

Asfaw, T. T., \& Bo, C. C. (2003). Student use of internet in China: A study on Huazhong University of Science and Technology (HUST). Pakistan Journal of Information and Technology, 2(1), 25-29.

Chan, K., \& Fang, W. (2007). Use of internet and traditional media among young people. Young Consumers, 8(4), 244-256.

Compeau, D. R., \& Higgins, C. A. (1995). Computer self-efficacy: Development of a measure and initial test. MIS Quarterly, 19(2), 89-211.

Fishbein, M., \& Ajzen, I. (1975). Belief, attitude, intention and behaviour: An introduction to theory and research. Reading, MA: Addison-Wesley.

Fusilier, M., \& Durlabhji. (2005). An exploration of student use in India: The technology acceptance model and theory of planned behaviour. Campus Wide Information Systems, 22(4), 233-246.

Hair, J. F., Anderson, R. E., Tatham, R. L., \& Black, W.C. (1998). Multivariate data analysis (5th ed.). New Jersey: Prentice Hall.

Harrison, D. A., Mykytyn, P. P., \& Riemenschneider, C. K. (1997). Executive decisions about adoption of information technology 
in small business: Theory and empirical tests. Information Systems Research, 8(2) 171-192.

Hartwick, J., \& Barki, H. (1994). Explaining the role of user participation in information system use. Management Science, 40(4), 440-465.

Jong, D., \& Wang, T.S. (2009). Student acceptance of web-based learning system. Proceedings of the 2009 International Symposium on Web Information Systems and Applications (WISA'09) (pp. 533-553). Nanchang, People Republic of China.

Limayem. M., Khalifa, M., \& Frini, A. (2000). What makes consumers buy from Internet? A longitudinal study of online shopping. IEEE Transaction on Systems, Man and Cybernatics, 30(4), 431-432.

Mathieson, K. (1991). Predicting user intentions: Comparing the technology acceptance model with the theory of planned behaviour. Information System Research, 2(3), 173-191.

Moore, G., \& Benbasat, I. (1993). An empirical examination of a model of the factors affecting utilization of information technology by end-users. Working paper Faculty of Commerce, University of British Columbia, Vancouver.

Noor Ismawati Jaafar. (2003). Computer usage and perception among accounting students: A survey in a public university. Jurnal Pendidikan, 23, 57-69.

Nunnally, J. C. (1978). Psychometric theory (2nd ed.). New York: McGraw Hill.

O'Cass, A., \& Fenech, T. (2003). Web retailing adoption: Exploring the nature of Internet users, web retailing behaviour. Journal of Retailing and Consumer Services, 10 (2), 81-94.

Taylor, S., \& Todd, P.A. (1995). Understanding information technology usage: A test of competing models. Information Systems Research, 6 (2), 144-176.

Yalcinalp, S., \& Moeini, H. (2008, September). University students' approach to ICT in their learning process. Paper presented at the European Educational Research Association Conference, Gothenburg, Sweden.

Yi, M. Y., Jackson, J. D., Park, J. S., \& Probst, J. C. (2006). Understanding information technology acceptance by individual professionals: Toward an integrative view. Information \& Management, 43 (3), 350-363. 